\title{
"Strands of Gumi Sasak Pearls" Harmony-based Tourism Products in Mataram City, West Nusa Tenggara
}

\author{
IDA AYU TRISNAWATI, I GUSTI LANANG OKA ARDIKA, ${ }^{2}$ I NYOMAN KARIASA ${ }^{3}$
}

1,2. Dance Department, Performing Arts Faculty, ISI Denpasar

3. Karawitan Department, Performing Arts Faculty, ISI Denpasar

E-mail : dayutrisna@gmail.com

\begin{abstract}
Penelitian ini merupakan penelitian yang bertujuan untuk mengidentifikasi kesenian etnis Sasak, Etnis Bali dan seni akulturasi di Kota Mataram. Hasil identifikasi selanjutnya dikemas dalam bentuk DVD Seni Pertunjukan dengan tema yaitu Untaian Mutiara Gumi Sasak. Cerita dalam DVD dibalut dengan kisah Dewi Rengganis yang nantinya memunculkan potensi seni dan etnis di Kota Mataram sehingga bisa menjadi tujuan wisata dunia.

Hasil penelitian menunjukan bahwa kehidupan masyarakat Kota Mataram cukup harmonis walaupun terdiri dari berbagai etnis seperti etnis Sasak sebagai penduduk asli, etnis Bali, Jawa, Melayu dan sebagainya yang merupakan penduduk pendatang. Keharomisan ini terbukti dari adanya pemahaman tentang keberadaan kotanya yang pluralisme, kemudian di praktekan dalam kehidupan yang toleransi sehingga menciptakan suatu kehidupan rukun yang menjadi modal masyarakat dalam mengembangkan diri. Situasi yang harmonis ini menarik sehingga diwujudkan dalam sebuah seni kolaborasi dengan tema Untaian Mutiara Gumi Sasak yang berceritakan tentang keberagaman seni budaya di Kota Mataram yang hidup harmonis. Cerita ini di balut dalam kisah Dewi Rengganis yang merupakn cerita asli suku Sasak. Hasil seni kolaborasi ini diharapkan menjadi salah satu nilai jual sekaligus produk wisata alternatif yang bisa membantu mewujudkan kota Mataram menjadi salah satu tujuan wisata dunia.
\end{abstract}

This research is aimed at identifying the Sasak ethnic art, Balinese ethnic and art acculturation in Mataram. Results of subsequent identification is packaged in a DVD for the Performing Arts with the theme of strands of Gumi Sasak pearls. The story in the DVD is wrapped with the story of Dewi Rengganis that will bring the potential of art and ethnicity in Mataram so that it can become a world tourist destination The results showed that people's lives of Mataram city are quite harmonious eventhough composed of various ethnic groups such as Sasak as indigenous people, Balinese, Javanese, Malay and so forth that they are migrant population. Harmony is evident from the understanding of the city pluralism, then practiced in the tolerance life that create a harmonious life that becomes public capital to develop themselves. This harmonious situation is so interesting that it is realized in a collaborative art with the theme of strands of Gumi Sasak pearls that tells about the diversity of art and culture in the city of Mataram that lives in harmony. This story is wrapped in the story of Dewi Rengganis that becomes an original story of Sasak tribe. The result of this collaborative art is expected to be one of the selling points and at once an alternative tourism product that could help realize Mataram city to be one of the world's tourist destinations.

Keywords: pluralism of arts, tourism potential, Mataram City 


\section{INTRODUCTION}

Mataram city ethnically is one of the cities with a high level of ethnic pluralism consisting of Sasak, Balinese, Javanese, Malay, and so forth. The largest tribe on the island of Lombok is Sasak. Islam adherents is the most predominant. Sasak tribe is known to have a bilief in telu time, that is the belief that has elements of Hindu, Buddhist, and other ancient traditional beliefs. The most ancient Sasak village is Bayan village near the foot of Mount Rinjani, which is a stronghold of waktu telu. In addition to the presence of the majority of the Sasak tribe, the existence of Balinese also provides color in the social life of the community of Mataram. Balinese has become a dominant immigrant tribe in this area. The existence of the Balinese here provide a distinctive color in the life of Balinese art and culture based on Hindu religious teachings. On the other hand the city of Mataram is the capital of West Nusa Tenggara province that developes into the center of various activities, in the field of government, educational centers, trade centers and services, shopping centers, transport links between regencies and provinces. The entrance of the West is the region of Ampenan Pasar Kebon Roek, the east is Pelabuhan Kayangan Labuan Lombok coming from the island of Sumbawa, the north is Gunung Sari district and Lingsar village West Lombok regency, and the southern is Pelabuhan Lembar caming from Padang Bai (Bali). It is inevitable also that the island of Bali and Lombok are two different islands in the Nusa Tenggara (NUSRA archipelago) and Indonesia. Since the beginning, the two communities interact with each other, not only in trade (economy) and politics but also in social aspects as well as arts and culture.

Such development makes the rhythm of economic and cultural city of Mataram fairly high. The influence of Bali that is close culturally and geographically also encourage Kota Mataram to develope as a tourist destination. The tourism development is becoming increasingly important, as tourism seems to increasingly contribute significantly to the economic, social, cultural, as well as employment and business opportunities for people in the city of Mataram.

To anticipate the opportunity the city of Mataram specifically and Lombok generally begins to hold various national events. These events become golden opportunity for the city of Mataram to sell various tourism potentials and uniqueness; District of Ampenan has recreation park with marine tourism, Ampenan beach with the sunset, Taman Bumi Gora with culinary tours, District of Cakranegara with Pura Meru, District of Sandubaya Mandalika Market, Van Ham Tomb, District of Mataram with Sangkareang Park, District of Sekarbela with Bangsal beach, historical tourism, cultural tourism, religious tourism, and the center of accessories and souvenirs. There are also a good variety of cultural festival as well as arts festival. In spite of the source potentials it will be very unfortunate if it could only be enjoyed by the local community alone, so real efforts are needed to develop it so that it can be known and enjoyed by all the people of Indonesia and the world through more practical promotions and product packaging since the diversity of art and culture is an asset or source of special attraction to be packaged, managed and offered as attractive products. Therefore, in order to improve the competitiveness of the object as well as arts and culture as a tourist attraction to Lombok, in particular to Mataram City, packaging models of traditional arts need to be done as a means of supporting the tourist attraction in the city of Mataram. It was from the phenomenon that finally an idea to pack the culture and richness of Mataram City was presented in the form of Arts Collaborative Performance packed in the Strands of Gumi Sasak Pearls with the story of Dewi Rengganis as the main character. In this story various performing arts potentials in Mataram will be raised so that it can be known by the public. Furthermore DVD versions of the Performing Arts will be produced or can also be staged directly to be one of the campaign media and at the same time to realize the potentials of the city of Mataram as a world tourism destination

\section{RESEARCH METHODS}

This study used a qualitative approach: data sources in this research are already known by the public in Mataram, the researcher as a research instrument, directly made observations, interviews and observations in the field. The data used are descriptive in nature, did not use numbers or statistics (quantitative). According to the source, data collection were done in an interactive and non-interactive techniques. The interactive technique based data collection is carried out in the form of intensive observations, interviews and non-interactive such 
as documentation.

The stages of research to obtain results in line with the research objectives, include four stages: preparation, data collection, processing and analysis of data, result presentation followed by production stages that are divided into three steps, namely First, Packaging implementation of traditional Art model of West Nusa Tenggara pengarapan as supporting facilities of tourist attraction in the city of Mataram, secondly, the feasibility test of the arts by the experts, followed by a revision of models. Thirdly, the field application involving figures of arts and culture, tourism practitioners, tourism agencies which are then followed by designing of the final model resulting in traditional arts packaging as a means of supporting the tourist attraction in the city of Mataram.

\section{DISCUSSION TOURISM PRODUCT OF "STRANSDS OF GUMI SASAK PEARLS"}

Mini DVD produced is a concise form of staging results that have been implemented in the previous stages. The first stage of research was identification of dances that exist in West Lombok consisting of Balinese dance, Sasak dance and acculturation dance. The results of research were then packaged in a performance held on the second stage. In the second stage, the production process of collaborative art form was carried out starting from preparation in the form of exercises done by dancers and drummers which later tested in the form of rehearsal. Once everything was ready the performance was carried out. The staging was held at Sasana Budaya Lombok, which was attended by the general public and elements of Muspida Mataram. A very rousing welcome came from the audience and the elements of the government encourage the researcher to make the product of research outcomes in the form of documentation that later can be used as a means of tourism promotion in West Lombok in general and specifically the city of Mataram.

The performed dances are classified into 3 groups: Sasak, Balinese and acculturation arts of Bali and Lombok. However, due to the huge number of dances some typical dances from different ethnics including acculturation dances. The selection was based on the popularity of dance, typical character istic of dance and the limited time of staging and costs required to perform. The chosen sasak dance is Beleq drum dance. The selected Balinese arts consist of the three arts including Nyiu Alit, Puspa Kanigara and Saraswati dances. As for the acculturation art: Kembang Sembah and Gandrung dances are choosen. All of them are packaged in the form of dance collaboration coupled with the story of the Sasak community, namely Dewi Rengganis Life Story. After staging documentation was done which was then produced in the form of mini-DVDs to be sold to tourists at the same time as a means of the tourism promotion in this area. Here is a brief description of each dance selected to be recorded in mini DVD containing Potential dances of Lombok for the promotion of tourism in the city of Mataram.

\section{1) Sasak Arts}

Beleq drum dance and oncer dance with a synopsis of Beleq drum oncer a type of dance performed while playing / hitting instrument. This type of dance is to describe the movements of war. But today's development shows that Beleq drum is used as a dance for welcoming guests. It is so called because the main instrument used to accompany the dance consists of two large drums (= beleq) that exceed the usual drum and dance at the same time function as dance property, as shown below.

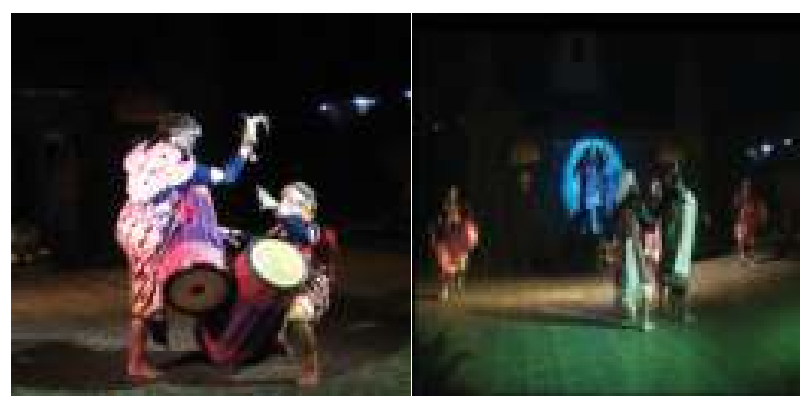

Picture 1: Kendang Beliq Dance Source: Dok. Dayu, 2015

Beleq drum dance performance with the story of Dewi Rengganis happens at the end in which due to the joy of king on his daughter's wedding various dances are performed on stage. The story of Dewi Rengganis is a public story very popular in Sasak community. This love story is filled with the values of compassion, sincerity, loyalty of lovers who really do look after each other. 


\section{2) Balinese Arts}

The first is Nyiu Alit dance with a synopsis as follows. Nyiu Alit Dance is a creation dance that departs from the activities of the community in the area of Lombok. Nyiu or nyiru is a tool to filter or rice winnowing traditionally to separate atah with rice, this dance is performed by some of the children dancers who took the basic elements from Balinese dance

As for the video, it is followed by their intact dance moves from the start to the end of dance as featured in the video used as an image, as follows

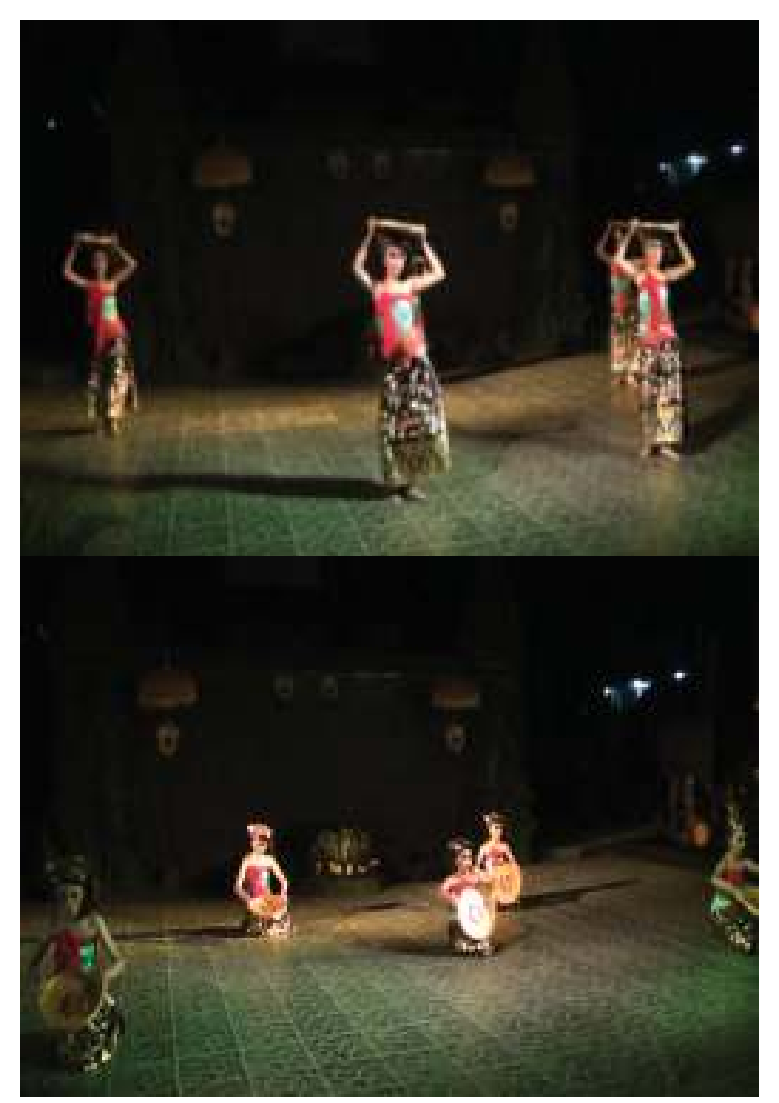

Picture 2 : Nyiu Alit Dance Source: Dok. Dayu, 2015

The second dance representing Balinese ethnic is a Dewi Saraswati dance that tells about Dewi Saraswati as a very beautiful goddess with four hands holding wina (musical instrument), kropak (holy Script), Genitri (Japa Mala), Lotus, and geese. Goddess Saraswati is the manifestation of Hyang Widhi as the god of Sciences.

As for the video, it is followed by the intact dance moves from the start to the end of dance as featured in the video used as an image, as follows

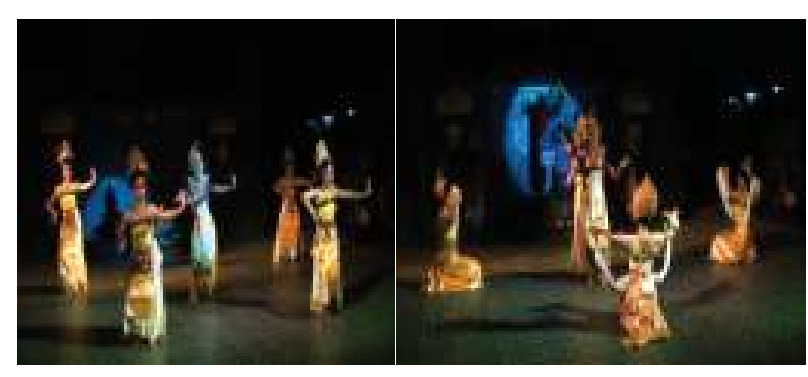

Picture 3: Saraswati Dance Source: Dok. Dayu, 2015

The third dance is a Puspa Kanigara dance that tells about a beautiful virtuous woman. The dance movements are very exquisite and full of inspiration and the image of elegance and nobility of a woman

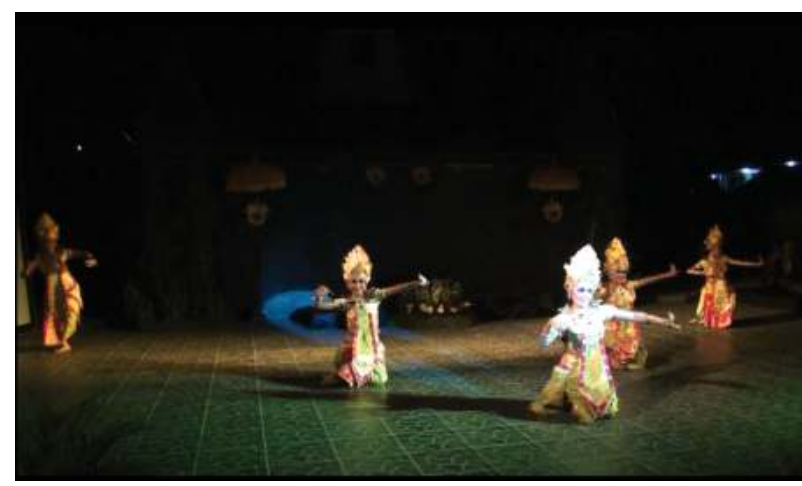

Picture 4: Puspa Kanigara Dance Source: Dok. Dayu, 2015

Those are the three dance performances staged in ther fragments of Strands of Gumi Sasak Pearls. The three fragments become a proof that in Lombok there are other ethnic groups which, if properly developed, become one of the cultural treasure of Mataram which could be sold in tourism package.

\section{3) Acculturation Arts}

The first is Kembang Sembah Dance with the synopsis that tells about the fun and excitement of society welcoming the arrival of guests. This dance is a welcome dance performed to welcome guests. As for the video, it is followed by the intact dance moves from the start to the end of dance as featured in the video used as an image, as follows (see picture 5) 


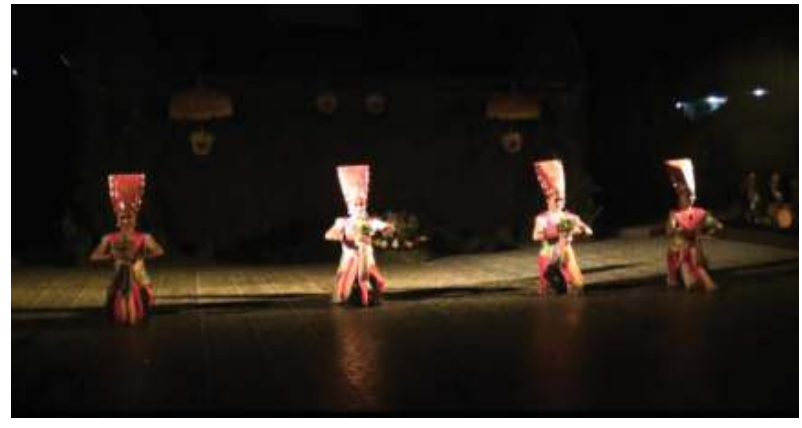

Picture 5 : Kembang Sembah Dance Source: Dok. Dayu, 2015

The second dance is Gandrung dance which was originally performed by men but now has been performed by women. Gnadrung dancers are commonly called "Gandrung" only. It is not clear how and when these changes occur. But a Gandrung dancer (woman) on each performance always introduces herself with the word "tiang lanang (I am a man)" and so on performed by way of singing called "basandaran" or "bedede". In "besandaran" always make self introduction with the term "tiang lanang". As for the video, it is followed by the intact dance moves from the start to the end of dance as featured in the video used as an image, as follows

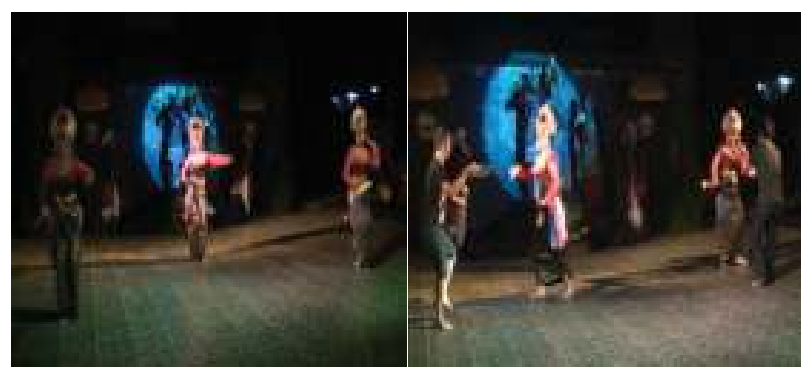

Picture 6: Gandrung Dance with the pengibing from the audience who participated in the staging Source: Dok. Dayu, 2015

The packaging of Strands of Gumi Sasak Pearls that combines Sasak, Bali and Acculturation dances in the city of Mataram is expected to be one of the promotion media and provide inputs to the regional government in developing tourism in the city of Mataram so that it could be one of the world's tourist destinations like in Bali. Mataram city in addition to having the cultural diversity around there also has many attractions to further promote the development of tourism in this area. Besides, it is geographically close to the island of Bali as an Indonesian tourism centre today so that it is easier for tourists to access this area either by sea or air. The existence of the International Airport in West Nusa Tenggara also opens direct flights to this area. These potentials and opportunities should be explored and developed continuously in order that Mataram city and West Nusa Tenggara can continue to evolve toward a better future, especially in realizing one of the world's tourist destinations.

\section{The Structure of String of Gumi Sasak Pearls story}

The first phase of the research has identified the variety of dances in Mataram. Further, the result of the first stage has been reproduced / repackaged in the second stage in the form of Strands of Gumi Sasak Pearls story that would become a bond of staging of art in the city of Mataram. The performing art is performed in a single story, but still presents local arts found in the city of Mataram. As a wrapping of ethnic art is the story of Dewi Rengganis which is the original story of Lombok. Selection of this art is of course based on various reasons, among others :

1. This dance is a reagional arts that are already very familiar in the community. Lombok society in general and Mataram city must already know this story, so of course people will easily accept and tour guides can explain it well to tourists as consumers later.

2. This art has meaning and positive values that benefit the community.

3. The story of Goddess Rengganis is also easily packaged and collaborated with other arts.

4. Easily collaborated so as to reduce the cost and time, so as not to swell the cost of research

The Strands of Gumi Sasak Pearls story in general is romance story that is the Love Story of Dewi Rengganis living in a kingdom with a king, Prabu Jayengrana who has a Crown Prince named Raden Rapatmaja. As a crown prince Raden Rapatmaja was provided by governmental science and that he was sent to study in a pedepokan. In his way he became acquainted with princess Haldakmas named Dewi Rengganis who was very beautiful

This acquaintanceship raises the seeds of love between them. After learning, Raden Repatmaja returned to his kingdom in a very long time, resulting in a very deep longing in the heart of Dewi Rengganis. To cure her longing, Dewi Rengganis 
went to the Yaksakambang park belonging to Raden Repatmaja hoping to meet with Raden Repatmaja there. During her stay in the park Dewi Rengganis marveled at the beauty of Yaksekambang park. Her hope to meet with Raden Repatmaja never diminished, but that hope remained only a mere hope for the lover who was expected to come but never turned up. But with her power Dewi Rengganis tried to pull the her arrow of love to call and evoke a sense of longing of Raden Repatmaja to her. Dewi Rengganis' effort is not in vain. Soon Raden Yaksekambang Repatmaja went to the park, and was very surprised when he saw princess Rengganis in the garden.

The meeting in Yaksekambang park made their love deepened. And in the park the two are mutually promised to love each other till dead and as soon be married. Coming home from the park Raden Repatmaja met his father and begged to bless his marriage to Dewi Rengganis. King Jayengrana was delighted to hear his request, and blessed the marriage between Raden Repatmaja with Dewi Rengganis. As a reflection of gratitude and excited the King announced and called on the people to celebrate the marriage of his son and daughter with a wonderful party and displayed various types of existing art such as: kendang beliq, presean, and other acculturation arts while parading the bride as a symbol of the prosperity of the gumi Sasak people.

The performance was conducted in two rounds in which the first half tell about the waiting of Dewi Rengganis for her lover at Yaksekambang park. Dewi Rengganis recalled wonderful stories when they met until finally they split up because the task of Raden Repatmaja to study has completed. In detail, the series of first round staging of the strands of Gumi Sasak pearl as follows.

Pepeson arrangement in the performance of the strands Gumi Sasak pearl are as follows: Act I

1. Dayang and Dewi Rengganis

2. Dewi Rengganis remembered his meeting with Raden Repatmaja (flashback )

3. The beauty of Yaksekambang

4. Dewi Rengganis in Yaksekambang Park

5. Dewi Rengganis was upset because she did not meet with Raden Repatmaja

6. Dewi Rengganis finally released her amorous arrows

\section{Raden Repatmaja went to Yaksekambang} park

8. Surprised to see Dewi Rengganis in Yakseka mbang park

9. Prince Repatmaja and Dewi Rengganis made love

10. Prince Repatmaja and Dewi Rengganis went home to their kingdom and ask for permission from their father

The next story will be preceded by Raden Repatmaja who met his father to beg for permission to propose Dewi Rengganis. Here is the climax of this love story at the same time the emergence of a variety of local arts / ethnic groups in Mataram city that will be performed to the audience or the tourists who come to see this show. The course of the story, includes namely:

Act II

1. Raden Repatmaja asked for the blessing of his father, King Jayengrana to propose Dewi Rengganis as his wife

2. The king was very happy and blessed the marriage

3. The King announced a big party to celebrate the marriage between Raden Repatmaja with Dewi Rengganis

4. A great variety of arts including Balinese dance, Lombok dance and mixed dance between Balinese and Lombok Dances: Welcoming Dance, Kendang Beliq, Presean, and ended with the closing in which everyone danced Gandrung while parading the bride and groom

After the performance of the Sasak, Balinese and acculturation dances in Mataram city the show ends. The story is short but full of artistic values and also evidence that Mataram city has a beautiful and unique culture with modern packaging that is short but hoped inherent in the memory of the visitors who come to the city of Mataram. Here are the synopsis of the Strands of Gumi Sasak Pearls that was read before the performance began.

The dance tells about the love story of two lovers named Rengganis Dewi princess of king Haldakmas with Raden Rapatmaja prince of King Jayengrana. Their love story begins with their meeting in a hermit age where the prince studies. Later they were separated because of the prince had completed his education, they finally met again in Yaksakambang 
Park. Their love blossomed again and promised to live till death did them part. Both ultimately delivered their wishes to their parents. Prince Rapatmaja's father welcomed the news with joy. He immediately summoned all royal courtiers to discuss the plan, a good day had been determined, a huge party was prepared, bustle was everywhere to celebrate a great day for the kingdom. The king ordered all the people of Lombok to celebrate this. The dances were staged as a form of gratitude and joy as well as evidence that the kingdom was rich in art and culture, there were reception dance, Kendang Beliq, Presean, and gandrung dance. Beautiful and high valued art and culture could make this kingdom prosperous and full of harmony. Joy was everywhere. So the story ended by staging a variety of local arts. All the arts become evidence that art is valueable and has the power to make people come together to create prosperity across the nation including Indonesia. Please enjoy.

Thus are the contents of tourim product of the Strands of Gumi Sasak Pearls serving as a means of tourism promotion in Mataram city, West Nusa Tenggara.

\section{STRANDS OF GUMI SASAT PEARLS AS A REPRESENTATION OF HARMONY IN MATARAM CITY}

Indonesia is one country in the world having a high level of cultural diversity. However, such diversity can actually be a double-edged sword. On the one hand, in a state of peace it can be a blessing. Preventing conflicts is far better than giving a solution after the conflict. Therefore, an understanding of respect for diversity needs to be introduced early. Inculcating this understanding to young people is the right choice. Young people are the most potential group in terms of diversity issues, potentially supporting tolerance of differences as well as foster the seeds of conflict.

Dialog will never be enough to foster tolerance. Another more dynamic and exciting way is required, one of them is cultural activity. Through art, youth plays two roles namely as consumer as well as producer. With the increasingly sophisticated and cheaper technology and equipment everyone is "encouraged" to become more productive. Anyone, with cameras, drawing tools, or whatever technique, can participate. The status of artists, students, or unemployed, is no longer a problem in the work. Departing from these ideas, the development model of dance that combines the culture of Bali and Lombok in Mataram can be used as an alternative solution and at the same time life model of tolerance by the community to live a national life with tolerance in the Republic of Indonesia whose ideology is Pancasila.

Art as one of the cultural elements of human existence has been progressing in a very long period of time starting from a simple form of art in prehistoric times up to more complex form in modern times today. A term of art in the Indonesian language is derived from Sanskrit meaning a request or search. The word Art (English) means skill, art (s) can be interpreted as activities or the result of human feelings of beauty (Sofyan Salam, 2001). Dance as a form of human behavior who has high artistic value continues to grow. Initially it is only performed in religious or traditional activities but then staged to the tourists to enjoy as one of the shows or attractions.

Based on the results of the first stage of the study it can be concluded that the development of art in the city of Mataram and Lombok is generally a result of cultural acculturation of various areas, especially later associated with the culture of Bali. This is in line with the historical development of Lombok itself once dominated politically by the kingdom of Karangasem, Bali. The statement of Drs. Then Suhemi Ismi, the Regional Official of the State Ministry of the Republic of Indonesia in NTB province, as published in http://hidupharianku.blogspot.com dated May 17, 2015, said that " Lombok Island as the twin brother of Bali" is not uncommon anymore for their attachment to the history and culture so strong between two clumps of cultures that are geographically very close together.

Acculturation between Sasak ethnic culture and Balinese as the majority population on the island of Lombok is a beautiful scenery of tolerance and inter-religious harmony. Balinese ethnic and culture strongly held by Hindu religious values remain stable coloring the daily life of Lombok community. Likewise with the Sasak people who are Muslims lead lives with full of religious tolerance. The value of tolerance and the spirit of multiculturalism 
become stronger with the artistic life that is sincerely performed and staged as an entertainment forum as well as complementary activities of the customs and culture.

This harmonious life in accordance with the educational concept of multiculturalism proposed by Gorski, i.e there are three main goals of multicultural education (which may be referred to as instrumental and terminal targets), namely

1. Elimination of educational discrimination, provide equal opportunities for every child to develop their potential (instrumental purposes);

2. Making children able to reach their academic achievement (internal terminal objectives);

3. Making the children socially conscious and active as citizens of the local community, national, and global (external terminal objec tives). (Gorski, 2010, Zamroni, 2011).

Holding onto the educational concept of multiculturalism in the development of artistic life in the city of Mataram of course could be one of the cities with the best level of tolerance in Indonesia. Multiculuralism educational attainment will indirectly promote the realization of national education goals better, reaching the basic principles of education. The sole principle of nationalism and national education goal is the achievement of Indonesian society based on Pancasila. A more detailed explanation can be found in Sartono Kartodirdjo. The principles of nationalism become the basis of national educational goals, because it contains values such as:

1. Unity through integration process in the history of solidarity that transcends national, local ethnic, traditional solidarities.

2. Liberty (freedom), the rights, freedom of speech, living in groups, with full freedom of internalized social responsibility of individu als are protected

3. Equality of rights and obligations, equality of opportunity

4. With regard to the 2 nd and 3 rd principles, there is the principle of personality or individuality. Private individuals are protected in the law including property rights, contracts, exemptions from communal and primordial bonds

5. Performance (work) either individually or collectively. Each group requires stimulation and inspiration to spur achievement to be proud of. (Kartodirdjo, 1993: 48)

A true understanding of multiculturalism ultimately creates an array of a tolerant society. People who have a tolerance reflected and can be fostered through dialogue can not be separated from the ideology of pluralism. Etimologically "... the term pluralism comes from the Latin root word, plus, pluris, which literally means: more than one. While the terminologically the meaning of pluralism is as follows.

"Pluralism refers to the awareness to live a legitimate coexistence in the diversity of thought, life, and behavior that in a particular side is actually incompat ible with each other. In the context of religion, this concept requires every religious believer not only acknowledge the existence and rights of others, but is also involved in all efforts to understand the differ ences and similarities in order to achieve harmony in diversity (A'la, 2001: 35).

Awareness of the diversity or pluralism, certainly would encourage the community in Mataram city to coexist harmoniously, in other words, inter-ethnic harmony can be realized. The harmony is an orderly society circumstances, full of peace with tolerance so as to create an atmosphere of harmony. The harmony is a tangible proof that society has reached the point of a comprehensive understanding and culminates thus no longer only in the framework of a theory but rather on social practices implemented in daily life. The illustration of social harmony can be seen in the following chart.

Based on the chart, the harmony in Mataram can be realized with steps: first comprehending the principle of harmony, identifying the barriers that can impede, and then determining what steps can be done so that the ultimate goal of achieving peace and unity of society can be realized.

The initial step in the process of realizing a peaceful and united society in Mataram starts with understanding the principles of harmony itself. The understanding has begun with an understanding of pluralism in this city. Harmony in Mataram society with various ethnic groups backgound such as Bali, Lombok, Malay, Java, and so has been tested by time because the people in the city of Mataram have 


\section{Chart of Social Harmony}

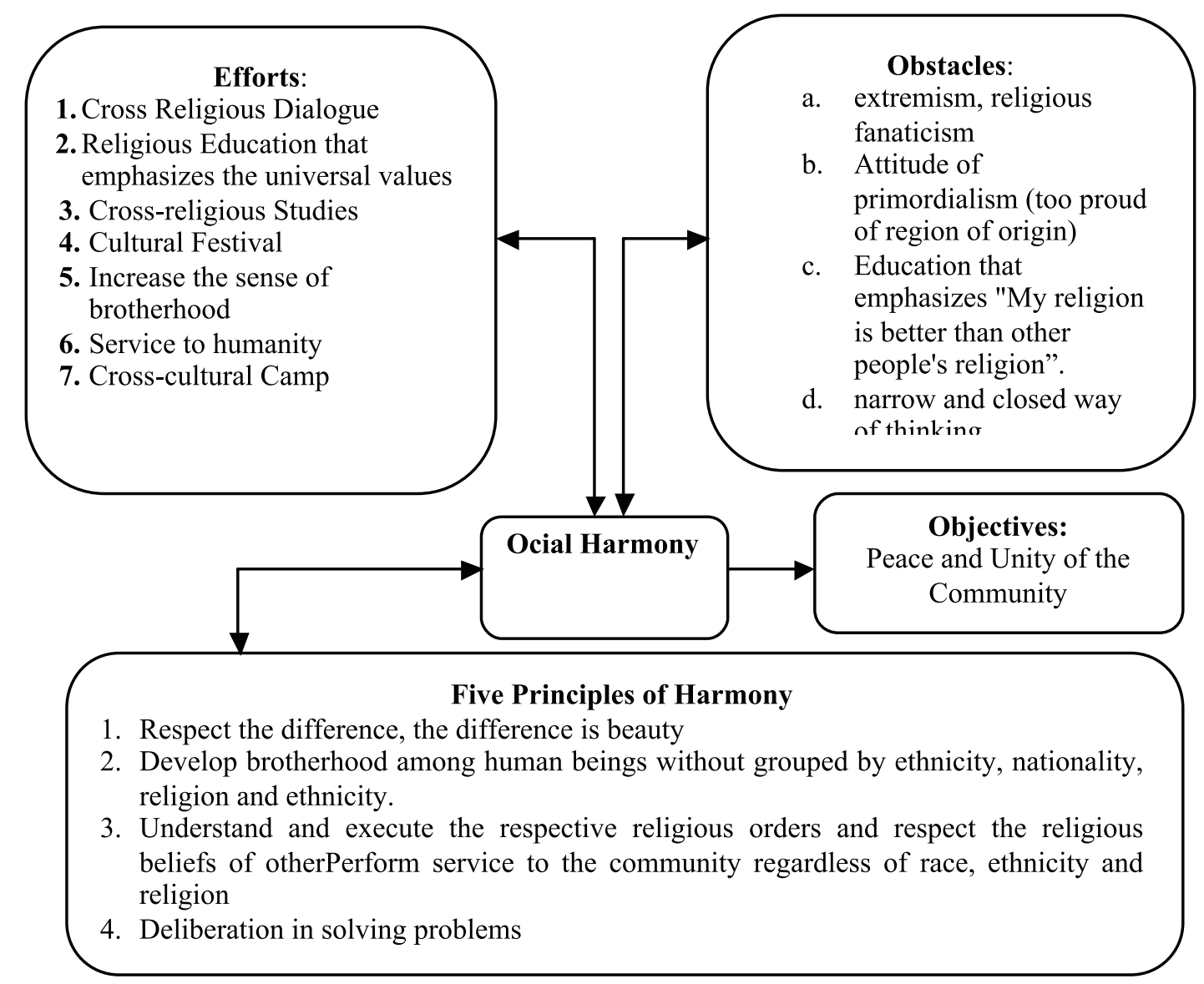

Source: Modified from Adi Wirawan, 2011:69

understood the principles of harmony as proposed Adi Wirawan (2011: 68), namely:

1. Respect the difference, the difference is beauty

2. Develop brotherhood among human beings without grouped by ethnicity, nationality, religion and ethnicity.

3. Understand and execute the respective religious orders and respect the religious beliefs of others. Find the sameness of univer sal values that are taught by every religion to his people. Every religion teaches compas sion, non-violence and peace.

4. Perform a service to the community regard less of race, ethnicity and religion. Service to the community is service to God.

5. Deliberation solve the problem. Any disputes and disagreements can be resolved by consen sus. Never force what is considered to be true to others.
The five above principles are always practiced in the social life of society in Mataram so as to create a harmonious society and filled with the values of harmony. The next is to identify what obstacles or challenges to be faced. The challenge in the realization of harmony includes

1. Extremism and religious fanaticism. Attitudes that are too extreme and fanatic sometimes close our eyes and our logical minds about others

2. Primordialism (too proud about region of origin). Indonesia as an archipelago with a variety of ethnic, tribes and very spacious geographical areas indeed has very high levels f difference

3. Education that emphasizes on "My religion is better than other religions". Like of primordi alism and fanaticism the elements of religious leaders sometimes teach things contradictive with our reality in Indonesia and Mataram in 
particular. Many religious leaders compare one ethnic or religion with other religions. So that the assumption that the religion embraced is regarded as a better religion than the religion of others.

4. This way of thinking is narrow and closed. The cause of all obstacles in achieving harmony in society must be our own minds. Narrow and enclosed mind about reality and the changing of times is the signal that life is not in harmony. Since everything comes from the intentions and thought therefore the devel opment of a better education should be ende voured so that our thinking is wide open to be the first step in creating a harmonious society in the city of Mataram. With the creation of harmony of course the economic development and tourism could be developed into a better direction.

The nderstanding of the above-mentioned obstacles prepares Mataram to realize harmony as capital in the development of this region as an ideal tourist destination that offers a harmonious life in society.

1. Cross-religion, ethnicity, tribe and culture dialogues is important in order to understand the teachings of the religion, culture, ethnicity and other tribes. Through this dialogue, preju dices and negative stereotypes to other commu nity groups can be reduced.

2. Religious education that emphasizes universal values. Religious education should not only express one's own regious advantages and vilify other people's religion, but most impor tantly how that religious teachings must be able to show the universal values of the various religions in the world. Universal value in question is a core value of the respec tive religious teachings such as love, toler ance, peace and compassion

3. Cross-religious Studies

4. Development of cross-religious studies is also important so as not to have an incorrect understanding towards others. Learning about other people's religion does not mean having to move to another religion but as our path to better conduct with others of different faiths

5. Cultural Festival

Another important thing that can be used to achieve harmony is the cultural festival. This cultural festival is the real form of reality of people's lives in the city of Mataram. This art is packaged well in certain events only, whereas on normal days the performing arts will be forgotten, sometimes in the society among they rarely use the arts as entertain ment. People much more frequently use of pop music, because it is considered modern. Various documentation photos above are all staged in the festival as evidence that the cultural festival could give a positive value in creating harmony in society

6. Increase the sense of brotherhood. Through tolerance and equipped with an understand ing of ethnicity and culture, positive attitude and brotherhood are expected to appear.

7. Service to humanity. Brotherly attitude will cause a sense of humanity and help one another. Mutual aid is a form of service to humanity and the harmony in society will be strong too

8. In realizing even stronger harmony, religious camp certainly could be an alternative so they can see and feel directly the religious activities conducted by other people directly during camp underway

\section{ARTS AND HARMONY AS CAPITAL TO REALIZE MATARAM CITY TO BECOME WORLD TOURIST DESTINATION}

In addition to the presence of comfortable and safe situations in the lives of its people, realizing Mataram city to become a world tourist destination a concerted planning is also needed. According to Yoeti (2008b: 48-49), there are several aspects that need to be known in tourism planning as follows

a. Tourists - the characteristics of travelers expected to come must be known

b. Transportation - to know how the condition of transportation infrastructure from and to the tourist destination.

c. Attractions / tourist objects - whether it meets three requirements, including something to see, something to do, and something to buy

d. Service Facility - whether service facilities have supported the activities of tourism, such as accommodation, restaurants, public services, etc.

e. Information and Promotion - how the dissemination of information and forms of promotion are best suited to promote tourist destinations 
This careful planning would further facilitate the potential development of Mataram in the fields of arts that are supported by the ethnic diversity in this area. When viewed in isolation, it seems there are very conflicting values between tourism and culture. Tourism as an industry clearly has a very prominent economic value, while culture has a cultural value that is separate from the economy (Sudarsono, 1999: 93). However, as an industry that is growing rapidly it can cause an inequality even lead to cultural backwardness as described by Ogburn. For example, our society can not display the art specifically for tourists, especially foreign tourists. This can be proved by looking at the cultural development from time to time in which the cultural development is caused by two things: internal factors, the owner of the culture and external factors. One of the external factors is the influence of foreign culture caused by tourism development. Therefore, the development of tourism in the city of Mataram could also be developed with the packaging of existing culture to become one of the triggers for the development of tourism in this area. This becomes a form of community participation in tourism development since the development of tourism in a region must be supported by the surrounding community. Community support can be directly involved in the various activities of tourism itself or indirectly by developing various products and supporting tourism facilities.

Back on the development of tourism and supporting resources of people in the region, the potential development of local communities should be developed to the maximum so that contributive to the advancement of tourism in the city of Mataram. From here we can develop a product of culture of mutual support in the development of tourism in the region of Lombok in general and Mataram city in particular. The foregoing discussion identifies that the potential of art and ethnicity in Mataram is very diverse. Then it can be used as one of the potentials developed in building community so that people do not experience cultural backwardness. Wimsatt in Sudarsono (1999: 95) explains how the connection between art as a part of the seven elements of culture by Koentjaraningrat can contribute in tourism. The form of contributions can be seen in the Winsatt schematic diagram below.

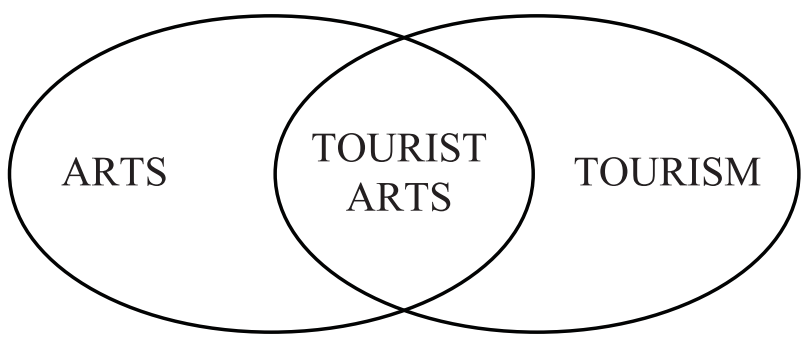

Picture 7 : Diagram of the relationship between art, travel and tourism

Source: Wimsatt Diagram in Soedarsono, 1999:15

The diagram above illustrates how the relationship between art and tourism that make up the travel art. Arts and tourism that contact would constitute a new form of art, i.e the art of travel. Travel art is an art that is shaped and created in order to meet the needs of tourism. Art is no longer merely created for the expression of the soul and spiritual needs of man, but has penetrated the culture of consumerism that is for the benefit of the economy (Lee, 2006).

This is in line with what was presented by Sudarsono (2003: 11) who explains that the development of tourism does not necessitate too high capital and can involve many sectors, such as transport, hotels, banks and also art. The only arts offered to tourists is "package arts" that has the following characteristics:

1. Copies of the original;

2. Short or solid, mini form from the original

3. The value of sacred, magical and symbolic are ruled out

4. Full of variation; and

5. Cheap price

Based on the above concept, the art began uprooted from its original roots and adaptive to the dynamic needs of artists and consumers resulting in imitation of art. The art performance for tourists look genuine but in fact it is only the engineering by artist with the aim to satisfy the curiosity and needs of consumers in tourism field.

Subsequent developments in various aspects of art results in a variety of miniature such as statues of deities, miniature of Prambanan temple, Borobudur in Central Java, which are made as souvenirs for tourists who come to the objects. Imitation not only penetrates the fine arts bu also the performing arts as many found in Bali such as Barong and Keris Dance performance, Kecak or Monkey Dance and 
Ramayana Ballet in Yogyakarta

Travellers are now very easy to enjoy art performances existing in various regions. Learning from this development a great opportunity to develop the same thing in Mataram is feasible by creating an art packaging. Art packaging in Mataram could be done more attractive by integrating the arts of various ethnic groups in the city of Mataram including Sasak and Balinese ethnics. Both of these arts can be packaged by wrapping it in a Strand of Gumi Sasak Pearls in which the story of Dewi Rengganis is presented as one of the Sasak community mythology as a story liaison and media of dance performances found Lombok in general and Mataram City in particular.

\section{CONCLUSION}

Based on the description above, there are several important conclusions that can be drawn, among others are:

1. The city of Mataram as the capital of West Nusa Tenggara has a diversity of art, one of them is a performing arts that is dances. This art is not only one type but consists of different types of dances that can be broadly divided into three groups: the original Sasak art. Two Balinese arts from local people as majority migrants in this area as well as the acculturation between Sasak art as native culture and Balinese culture as a culture of immigrants. The most important value of cultural diversity is the values of tolerance and togetherness embodied in the life of art. A positive value in the life of art in the form of tolerance and cooperation can be packaged as one educational model of multiculturalism that can be used as an example of other regions in facing with inter-ethnic conflict.

2. Cultural acculturation model and the potential range of art in the city of Mataram are not only of high aesthetic and religious values but in its development can also be packaged in the form of cultural tourism products. This phenomenon can be compared to the life of the Balinese culture on the island of Bali that is growing rapidly amid the sparkling life of tourism. Therefore, this great potential should be developed and given sufficient space in order to continue to develop into one of the life support of alternative tourism in the city of Mataram. Collaboration dance models packaged in a local story of Dewi Rengganis as proposed here can be developed further so that the tourism choices in Mataram, are getting better and better.

\section{REFERENCES}

Agung, Anak Agung Ketut. 1991. Кири Кири Kuning Yang Terbang Di Selat Lombok. Denpasar : PT. UPADA SASTRA.

Daeng, Hans J. 2000. Manusia, Kebudayaan dan Lingkungan.Yogyakarta: Pustaka Pelajar.

Damanik, Janianton dan Helmut F Weber. 2006. Perencanaan Ekowisata: dari Teori ke Aplikasi.Yogyakarta: Andi Ofset.

Djelantik, A.A.M. 1999. Estetika Sebuah Pengantar. Bandung: Masyarakat Seni Pertunjukan Indonesia.

Gorski, Paul C. 2010. "The Challenge Of Defining 'Multicultural Education'."

.www.edchange.org/multicultural/initial.html.

Diakses 19 Mei 2015.

Kartodirdjo, Sartono. 1993. Pembangunan Bangsa. Yogyakarta: Aditya Media

Kartodirdjo, Sartono. 1994. 'Metode Penggunaan Bahan Dokumen' dalam Koentjaraningrat (ed), Metode-metode Penelitian Masyarakat, Edisi ketiga. Jakarta: PT. Gramedia Pustaka Utama.

Karyono, A. Hari. (1997). Kepariwisataan. Jakarta: Grasindo.

Koentjaraningrat. 1990. Pengantar Ilmu Antropologi. Jakarta: Rineka Cipta.

Nawawi. 1992. Instrumen Penelitian Bidang Sosial. Yogyakarta: Gadjah Mada University Press.

Paturusi, S. A. 2005. Perencanaan Tata Ruang Kawasan Pariwisata (tesis). Denpasar: Universitas Udayana.

Safi'I, Lalu. 1999. Suku Sasak dalam Dekapan Budaya Cetakan Pertama. Jakarta: PT Ardadizya. 
Sachari, Agus. 1989. Estetika Terapan. Bandung: Nova.

Sachari, Agus. 2006. Estetika Makna, Simbol Dan Daya. Bandung: ITB

Sanderson, S.K. 1993. Sosiologi Makro Sebuah Pendekatan Terhadap Realitas Sosial. (Penerjemah F.Widjidi dan S Menno). Jakarta: PT Raja Grafindo Persada.

Sehita, Ricard. 2000. Tourism Industry (Kepariwisataan). Surabaya: SIC.

Setyawati, Edi.1984. Tari. Jakarta: Pustaka Jaya.

Soedarsono, R.M. 1998. Seni Pertunjukan Indonesia di Era Globalisasi. Jakarta: Direktorat Jenderal Pendidikan Tinggi Departemen Pendidikan dan Kebudayaan.

Soedarsono, R.M. 1999. Seni Pertunjukan dan Pariwisata. Yogyakarta: ISIYogyakarta.

Sugiyono. 2007. Memahami Penelitian Kualitatif, Dilengkapi Contoh Proposal Dan Laporan Penelitian. Bandung: CV. Alfabeta.

Suwantoro, Gamal. 2005. Dasar-Dasar Pariwisata. Yogyakarta: Andi Ofset.
Suweda. I Ketut. I Gst. Ngr Widyatmaja. 2010. Pengantar Dasar Imu Pariwisata. Universitas Udayana: Universitas Udayana Press.

Taufiq, Warsaidarto. 1996. Mengenal Tari Daerah Nusa Tenggara Barat Cetakan Pertama. Jakarta: Yudhistira.

Wirawan, Made Adi. 2011. Hidup Rukun Menurut Hindu (Kerukunan Masyarakat Plural). Surabaya: Paramitha.

Taufiq, Warsaidarto. 1996. Mengenal Tari Daerah Nusa Tenggara Barat. Jakarta: Yudistira.

Yaningsih Sri Et Al. Tari Gandrung. Jakarta: Proyek Penelitian dan Pencatatan Kebudayaan Daerah Departemen Pendidikan dan Kebudayaan RI.

Yoeti, Oka A. 1996. Pengantar Ilmu Pariwisata. Jakarta: PT. Perca.

Yoeti, Oka A. 2006b. Perencanaan dan Pengembangan Pariwisata. Jakarta: PT Pradnya Paramita.

Zamroni. 2011. Pendidikan Demokrasi Pada Masyarakat Multikultural. Yogyakarta: Gavin Kalam Utama 